\title{
PSIKODRAMA TERAPI
}

Freeska Anjelly Lopuhaa

\section{Bimbingan dan Konseling}

Fakultas Pendidikan dan Bahasa

Universitas Katolik Indonesia Atma Jaya Jakarta

freeskaanjelly08920@gmail.com

\begin{abstract}
Abstrak : Tujuan dari psikodrama ini adalah membantu seorang remaja atau sekelompok remaja untuk mengatasi permasalahan pribadi dengan menggunakan permainan peran, drama, atau terapi tindakan. Lewat cara-cara ini remaja dibantu untuk mengungkapkan perasaanperasaan tentang konflik, kemarahan, agresi, perasaan bersalah, dan kesedihan. Psikodrama pada dasarnya adalah melakukan aksi (pertunjukan drama) dengan dorongan jiwa. Maka bisa didefinisikan bahwa psikodrama adalah ilmu yang mengeksplor suatu masalah dengan metode drama.
\end{abstract}

\section{Kata kunci : Psikodrama, Terapi}

\section{PENDAHULUAN}

Psikodrama adalah metode atau tindakan yang sering digunakan sebagai psikoterapi, di mana klien menggunakan dramatisasi spontan, bermain peran, dan presentasi diri yang dramatis untuk mengungkapkan dan mendapatkan wawasan tentang kehidupan mereka. Psikodrama mencakup elemen teater, sering dilakukan di atas panggung, atau ruang yang berfungsi sebagai area panggung, di mana alat peraga dapat juga digunakan. Terapi Kelompok psikodrama, yang dilakukan di bawah arahan psikodramatis berlisensi, memperagakan kembali kehidupan nyata, situasi di masa lalu (atau proses mental batin), melakukan semua itu di masa sekarang. Peserta kemudian memiliki kesempatan untuk mengevaluasi perilaku itu semua, merefleksikan bagaimana insiden masa lalu dimainkan di masa sekarang dan lebih dalam memahami situasi tertentu dalam kehidupan mereka.

Psikodrama menawarkan cara kreatif bagi individu atau kelompok untuk mengeksplorasi dan memecahkan masalah pribadi. Ini dapat digunakan dalam berbagai setting klinis dan berbasis komunitas, dan paling sering digunakan dalam setting kelompok, di mana anggota kelompok berfungsi sebagai agen terapeutik satu sama lain dalam drama yang ditetapkan. 


\section{PEMBAHASAN}

Terapi, atau pengobatan, adalah remediasi masalah kesehatan, biasanya mengikuti diagnosis. Orang yang melakukan terapi disebut sebagai terapis. Dalam bidang medis, kata terapi sinonim dengan kata pengobatan. Terapi tersendiri memiliki berbagai macam dari cognitive behavioural theraphy, Interpersonal theraphy, Terapi pernikahan dan keluarga, Psychodynamic theraphy, Terapi seni, Psikoedukasi, dan hipnoterapi.

Psikodrama adalah metode atau tindakan yang sering digunakan sebagai psikoterapi, di mana klien menggunakan dramatisasi spontan, bermain peran, dan presentasi diri yang dramatis untuk mengungkapkan dan mendapatkan wawasan tentang kehidupan mereka. Psikodrama mencakup elemen teater, sering dilakukan di atas panggung, atau ruang yang berfungsi sebagai area panggung, di mana alat peraga dapat juga digunakan.

Terapi psikodrama adalah salah satu jenis terapi yang paling sering digunakan untuk anak yang mengamalami gangguan, seperti anak yang mengalami gangguan perhatian (ADD). Psikodrama adalah metode pembelajaran dengan bermain peran yang bertitik tolak dari permasalahan-permasalahan psikologis. Psikodrama biasanya digunakan untuk terapi, yaitu agar siswa memperoleh pemahaman yang lebih baik tentang dirinya, menemukan konsep diri, menyatakan reaksi terhadap tekanan-tekanan yang dialaminya. Psikodrama merupakan suatu permainan peran yang dilakukan agar individu yang bersangkutan dapat memperoleh pengertian yang lebih baik tentang dirinya untuk dapat menentukan konsep dirinya menyatakan kebutuhannya dan reaksi terhadap tekanan terhadap dirinya (Corey 1985).

Teknik psikodrama merupakan salah satu teknik dalam konseling kelompok yang dapat digunakan konselor dalam menangani masalahmasalah emosional. Psikodrama merupakan suatu bentuk terapi kelompok, dimana anggota kelompok didorong untuk memainkan suatu peran emosional didepan para penonton, tanpa dilatih sebelumnya dengan tujuan untuk membantu anggota kelompok dalam mengatasi masalah-masalah pribadi dengan menggunakan permainan drama, peran/terapi tindakan yang akhirnya akan menggungkapkan perasaanperasaan tentang konflik, kemarahan, agresif, perasaan bersalah dan kesedihan. Melalui bermain peran remaja dibantu untuk mengungkapkan perasaanperasaan tentang konflik, kemarahan, agresi, perasaan bersalah dan kesedihan. Emosi yang ada dalam diri remaja diungkapkan ketika remaja memainkan drama, dengan demikian remaja dapat melihat dan mengetahui keadaan dirinya melalui permainan peran yang diperankan sesuai dengan keadaan dirinya. Peserta didik leluasa mengungkapkan segala yang ada dalam dirinya. Setelah peran 
diberikan refleksi dan masukan dari remaja-remaja yang menyaksikan peranyang dimainkan, sehingga menjadi gambaran tentang keadaan dirinya. Secara spesifik, kelompok psikodrama dan kelompok bantuan diri didisain dengan struktur dan dinamika. Karenanya pendekatan ini bekerja dengan orang lain (difokuskan pada kelompok).

Lubis (2016) mengemukakan lima elemen dasar dalam psikodrama, yaitu protagonis, pemimpin psikodrama atau sutradara, peran pembantu, penonton, dan panggung. Lubis (2016) juga mengemukakan teknik utama dalam psikodrama, yaitu; 1) creative imagery, 2) the magic shop, 3) sculpting, 4) teknik berbicara, 5) monodrama, 6) the double and multiple double techniques, 7) role reversals, 8) teknik cermin. Menurut Blatner (2000), psikodrama dilakukan dengan tiga tahap, yaitu warming up, action, dan sharing atau closing. Psikodrama efektif untuk meningkatkan kemampuan bermain drama (Siregar, 2015), mengembangkan konsep diri positif (Pramono, 2013), mengembangkan kontrol diri (Sari, 2017), dan menurunkan burnout (Wati, Budiono, \& Mutakin, 2018).

\section{Komponen Dalam Psikodrama}

Terdapat komponen dalam psikodrama menurut Yeni Hesti (2017);

1) Panggung permainan (Stage):

- Tempat untuk beraksi atau tempat sebagai permainan psikodrama berlangsung, yaitu didepan kelas, dengan tempat yang luas untuk member ruang gerak bagi pemeran dalam permaian psikodrma.

- Tempat tiruan harus merupakan tiruan atau paling tidak secara simbolis mewakili adegan-adegan yang diuraikan klien.

2) Pemimpin Psikodrama:

- Dalam psikodrama yang menjadi pemimpin kelompok adalah konselor atau terapis, pemimpin kelompok bisa dikatakan sebagai sutradara.

- Peranan pemimpin kelompok ini sebagai fasilitas, procedure dan pengamat/penganalisis. - Pemimpin kelompok memiliki sifat kreatif, berani.

- Tugas dari pemimpin kelompok ini adalah membantu pemegang peran utama, merencanakan pelaksanaan, mengamati dengan cermat perilaku pemain utama selama 
psikodrama berlangsung, membantu klien mengungkapkan perasaan secara bebas dan membuat interpretasi.

3) Pemeran Utama (Protaginist) :

- Peran utama (protagonist) disini sebagai subjek utama dalam pemeran psikodrama, memiliki sifat yang spontan dalam memainkan dramanya.

- Tugas dari pemain utama ini adalah memainkan kembali kegiatan penting yang dialami waktu lampau, sekarang, dan situasi yang diperkirakan akan terjadi, menentukan kejadian atau masalah yang akan dimainkan, melakukan peran secara spontan, memilih dan mengejar pemain lain yan terpilih terhadap peran apa yang dimainkan berdasarkan masalah protagonist.

4) Pemeran Pembantu (Auxilliaries) :

- Pemeran pembantu sebagai objek lain atau orang lain yang berarti dalam permainan tersebut bisa pula disebut sebagai actor.

- Fungsi pemeran pembantu untuk menggambarkan peranan-peranan tertentu yang mempunyai hubungan dekat dengan protagonist dalam kehidupan sebenarnya.

5) Penonton (Audience):

- Yang menjadi penonton (audience) yaitu anggota-anggota kelompok yang tidak menjadi pemeran utama atau pemeran pembantu.

- Memiliki tugas memberikan dukungan/feedback - Penonton juga membantu peran utama (protagonist) dalam memahami akibat perilaku protagonist.

\section{Kelebihan dan Kekurangan Psikodrama}

Kelebihan dari psikodrama ini adalah Dapat mengembangkan kreativitas remaja (dengan peran yang dimainkan remaja dapat berfantasi), dapat memupuk kerjasama antara siswa, menumbuhkan bakat remaja dalam seni drama, remaja lebih memperhatikan pelajaran karena menghayati sendiri memupuk keberanian berpendapat di depan kelas melatih remaja untuk menganalisa masalah dan mengambil kesimpulan.

Kekurangan dari psikodrama adalah Adanya kurang kesungguhan, terlihat malu-malu saat memerankan drama, sehingga para pemain menyebabkan tujuan tak tercapai, pendengar (remaja yang tak berperan) sering mentertawakan tingkah laku pemain sehingga merusak suasana. 


\section{Peran Konselor dalam Psikodrama}

Konselor dalam psikodarama berperan sebagai sutradara yang memiliki banyak peran. Sutradara berperan sebagai produser, fasilitator, pengamat, dan seorang analis. Seorang sutradara seyogianya membangun keterampilannya dalam tiga bidang yang saling tergantung, yaitu:

- Pengetahuan tentang metode-metode, prinsip-prinsip, dan teknik-teknik.

- Pemahaman tentang teori kepribadian dan hubungannya dengan pengembangan pembentukan filosofi hidup.

- Pematangan dan perkembangan kepribadiannya sendiri. Ia juga menambahkan bahwa ilmu pengetahuan yang luas tentang hidup dan hakikat manusia, seorang sutradara diharapkan memiliki kerja khusus dalam bidang pokok seperti psikologi umum, proses kelompok, psikologi humanistik, teori komunikasi, dan komunikasi nonverbal.

\section{KESIMPULAN}

Dalam psikodrama, individu dibantu untuk mengungkapkan perasaan tentang konflik, agresi, perasaan bersalah, dan kesedihan. Dengan psikodrama, diharapkan individu dapat mengungkapkan perasaannya. Hal ini sejalan dengan asertivitas, yaitu kemampuan untuk mengemukakn perasaan jujur dengan nyaman. Dalam psikodrama ini, individu dapat menyadari bahwa memiliki hak untuk asertif karena asertivitas penting dimiliki oleh remaja sejak dini. 


\section{DAFTAR PUSTAKA}

Blatner, A. (2000). Foundation of psychodrama, fourth editiion. New York: Springer Publishing Company.

Lubis, N.L. (2016). Konseling kelompok. Jakarta: Kencana.

Pramono, A. (2013). Pengembangan model bimbingan kelompok melalui teknik psikodrama untuk mengembangkan konsep diri positif. Jurnal Bimbingan Konseling, 2(2), 99-104.

Sari, S.P. (2017). Teknik psikodrama dalam mengembangkan kontrol diri siswa. Jurnal Fokus Konseling, 3(2), 123-137.

Siregar, T.S. (2015). Efektivitas metode psikodrama dalam meningkatkan kemampuan bermain drama oleh siswa kelas XI SMA Negeri 1 Stabat. Jurnal Edukasi Kultura, 2(2), 115-126.

Wati, N.I., Budiono, A.N., \& Mutakin, F. (2018). Bimbingan konseling dengan teknik psikodrama untuk menurunkan burnout pada siswa. Jurnal Consulenza, 1(1), 21-28.

Yusi Henita, Volume 1 (2017), Layanan Konseling Kelompok Teknik Psikodrama dalam Meningkatkan Kecerdasan Emosional Siswa Kelas VII SMPN 19 Bandar Lampung Tahun Ajaran 2016/2017, Jurnal Mahasiswi Prodi Bimbingan dan Konseling Fakultas Tarbiyah dan Keguruan Institit Agama Islam Negeri Raden Intan Lampung. 